\title{
Review Article \\ Potential for Application of Retroreflective Materials instead of Highly Reflective Materials for Urban Heat Island Mitigation
}

\author{
Jihui Yuan, Kazuo Emura, and Craig Farnham \\ Graduate School of Human Life Science, Osaka City University, Osaka 558-8585, Japan \\ Correspondence should be addressed to Jihui Yuan; yuanjihui@hotmail.co.jp
}

Received 10 January 2016; Accepted 26 January 2016

Academic Editor: Thomas Panagopoulos

Copyright ( 2016 Jihui Yuan et al. This is an open access article distributed under the Creative Commons Attribution License, which permits unrestricted use, distribution, and reproduction in any medium, provided the original work is properly cited.

\begin{abstract}
Research on urban heat island (UHI) mitigation has been carried out globally. Several strategies have been proposed or developed to mitigate UHI, including highly reflective (HR) envelopes of buildings, green roofs, urban vegetation, shading, heat sinks, and air-conditioning efficiency. Among these techniques, HR envelopes have been extensively studied as an effective method to mitigate the UHI effect by reducing energy consumption. However, because most of HR materials are diffusive, HR envelopes applied to vertical surfaces can reflect both onto roads and nearby buildings. Additionally, HR roofs cannot reflect all incoming solar radiation to the sky if there are high buildings around it. Thus, HR materials applied as building envelopes have a limited effect against the solar contribution to the UHI. In order to solve this problem, retroreflective (RR) materials, which reflect the solar radiation back towards the source, have been studied and developed to be applied as building envelopes instead of HR materials. This paper summarizes several previous researches on HR envelopes and cool roofs and summarizes several current researches on $\mathrm{RR}$ materials. The potential for application of RR envelopes in cities is proposed with consideration of economic and environmental factors.
\end{abstract}

\section{Introduction}

The urban heat island (UHI) effect is a serious challenge to energy conservation in urban centers in urban canyons over the summer period. A significant spatial and temporal variation is observed in the UHI intensity; many cities show a temperature $5-10^{\circ} \mathrm{C}$ higher than surrounding rural areas by midmorning [1]. The UHI effect could lead to increases in energy consumption for cooling [2], increased peak electricity demand [3], and degraded air quality [4]. Countermeasures to mitigate the UHI effect are being implemented by many researchers around the world [5-9].

As one of the most effective measures to reduce the UHI effect and an acknowledged solution for energy savings, highly reflective (HR) envelopes applied as building external walls have been investigated in several countries [10-15]. HR roofs have similarly been studied widely $[16,17]$. HR roofs can reflect solar radiation to the sky if there are no high buildings around it. However, if there are high buildings nearby, part of the reflection will be absorbed by those neighboring buildings. HR envelopes applied to vertical surfaces can also reflect onto roads, causing them to become hotter, so the total effect against the UHI is limited. To solve this problem of HR materials used for vertical outer walls, a variety of retroreflective (RR) materials began to appear on the market that can reflect the incident solar radiation back towards the source. However, those RR materials are mainly employed for various safety and decorative purposes, for improved visibility under low light conditions. They are not commercially available for application to building envelopes in Japan. The application of RR materials as new urban coatings is a novel research field and has some potential to (i) reduce the heat content in the UHI boundary; (ii) reflect solar radiation beyond the urban canopy; (iii) reduce the interbuilding effects in terms of mutual reflection. Glass beads and prism-arrays are the common main components of RR materials. In order to encourage use of RR materials more widely, the RR properties of these materials and the thermal-energy impact of these RR building envelopes are being studied internationally $[16,18-23]$.

Solar reflectance of building envelopes and urban pavement represents an important optic-energetic property for 
TABLE 1: Summary of influence of HR envelopes on the surface temperatures.

\begin{tabular}{|c|c|c|}
\hline Reference & Methodology & Surface temperature change \\
\hline$[30]$ & Using CFD simulation and TRNSYS. & $\begin{array}{l}\text { In a typical summer period, the surface temperature decreased } \\
\text { up to } 12^{\circ} \mathrm{C} \text {. }\end{array}$ \\
\hline [31] & $\begin{array}{l}\text { Using weather research and forecasting (WRF) v3.2.1 } \\
\text { model. }\end{array}$ & $\begin{array}{l}\text { Summer afternoon temperature in urban locations reduces by } \\
0.11-0.53^{\circ} \mathrm{C} \text { and some rural locations show temperature } \\
\text { increases of up to } 0.27^{\circ} \mathrm{C} \text {. }\end{array}$ \\
\hline [32] & Monitoring roof surface units by experiment. & $\begin{array}{l}\text { Daytime temperature of gray paint is almost } 10^{\circ} \mathrm{C} \text { higher than } \\
\text { that of white paint in August. }\end{array}$ \\
\hline [33] & $\begin{array}{l}\text { Installing a cooling roof and measuring temperature } \\
\text { and so forth. }\end{array}$ & $\begin{array}{l}\text { From April to September, temperature of roof decreased up to } \\
20^{\circ} \mathrm{C} \text {. }\end{array}$ \\
\hline$[34]$ & Monitoring white and black roofs. & $\begin{array}{l}\text { On a warm day, a reduction of } 26^{\circ} \mathrm{C} \text { by white roof in } \\
\text { midafternoon occurs. }\end{array}$ \\
\hline [35] & $\begin{array}{l}\text { Applying reflective roofs on two small nonresidential } \\
\text { buildings and measuring temperature and so forth. }\end{array}$ & $\begin{array}{l}\text { Average reduction of about } 10^{\circ} \mathrm{C} \text { in daytime during the summer } \\
\text { period occurs. }\end{array}$ \\
\hline [36] & Using energy balance model. & Temperature reduction of up to about $15^{\circ} \mathrm{F}$ in July occurs. \\
\hline [37] & Using TRNSYS software. & Temperature reduction of up to $25^{\circ} \mathrm{C}$ during summer occurs. \\
\hline
\end{tabular}

the characterization of building energy performance for cooling and to mitigate the summer UHI effect [24-28]. The solar reflectance of a building envelope can be calculated by means of spectrophotometer measurement of the material itself and knowing the solar radiation absorbed by the building envelope. Corresponding to solar reflectance of diffusive building envelopes, retroreflectance refers to the ability of a specially engineered surface to preferentially reflect incident sunlight back towards its source. Methods to derive the retroreflectance of RR materials are summarized by many researchers, and the effects of RR envelopes on building energy saving are also examined by simulations $[16,18,19,22,23]$. However, there is still little research on practical application of RR materials for building external walls.

This paper reviews previous research on HR envelopes, such as the effect of HR envelopes on environment temperatures, effect of HR envelopes on building energy consumption, and effect of HR envelopes on UHI intensity. Second, because HR envelopes have some drawbacks on reflective direction, being not able to reflect the incoming sunlight on building external envelope back towards the source, the objective of this paper is to provide a synthetic overview of application possibility of RR envelopes instead of HR envelopes in cities with consideration of economic and environmental factors.

\section{Influence of HR Envelopes on the Surface Temperatures}

Solar reflectance or retroreflectance of building envelopes determines the amount of solar radiation reflected from the building external envelope. The effect of HR materials has been examined in many previous researches, especially the effect of HR envelopes on the building surface temperatures [29-36]. Table 1 summarizes the main results of researches on impacts of HR materials on surface temperature in simulations and experiments.
The work in the Athens area by Santamouris et al. [29] shows that the use of cool pavements contributes to decreasing the peak ambient temperature during a typical summer day, by up to $1.9^{\circ} \mathrm{C}$, and the surface temperature in a park was reduced up to $12^{\circ} \mathrm{C}$ in parallel. The overall analysis shows that use of cool pavements is an efficient mitigation strategy to reduce the strength of UHI effect.

Millstein and Menon [30] used the weather research and forecasting (WRF) model to investigate feedback between surface albedo changes, surface temperature, precipitation, and average cloud cover. It shows that the afternoon summertime temperature in urban locations was reduced by $0.11-$ $0.53^{\circ} \mathrm{C}$ with the adoption of cool roofs and pavements.

Observations by Takebayashi and Moriyama [31] show that the daytime temperature of $\mathrm{HR}$ gray paint on building roof is almost $10^{\circ} \mathrm{C}$ higher than that of $\mathrm{HR}$ white paint in August. The surface temperature of a green roof is several degrees lower than that on bare soil surface, and it is several degrees higher than that of HR white paint. However, the surface temperatures of a green roof and bare soil are approximately the same in November. It is considered that, due to evapotranspiration, the surface temperature of a green roof in summer is lower.

The experimental work related to a cool roof application on a $700 \mathrm{~m}^{2}$ roof in Trapani, Sicily, was carried out by Romeo and Zinzi [32]. The results show that roof temperature decreased by up to $20^{\circ} \mathrm{C}$ from April to September, and average indoor air temperature reduced by 2.9 and $3.1^{\circ} \mathrm{C}$ in two studies rooms. The cooling and total net energy demand also decreased by about $3.8 \%$, due to the cool roof.

Simmons et al. [33] constructed a total of 24 experimental roof platforms in Austin, Texas, representing black, nonreflective roofs, white reflective roofs, and six different green roof designs, to compare their roof temperatures. It showed that maximum green roof temperatures were cooler than conventional roofs by $38^{\circ} \mathrm{C}$ at the roof membrane and $18^{\circ} \mathrm{C}$ inside air temperature. Also the experiment showed that white reflective roofs are at average $26^{\circ} \mathrm{C}$ cooler than black roofs in midafternoon on a warm day. 
Akbari's work [34] applied reflective roofs on two small nonresidential buildings with roof area of $14.9 \mathrm{~m}^{2}$ during summer of 2000 . The original solar reflectivity of roofs was about 0.26 . After the application of roof coatings, the reflectivity was increased to about 0.72 . The result of this experimental work showed that the average roof temperature decreased about $10^{\circ} \mathrm{C}$ in daytime in summer. Additionally, it showed that a reflective roof could save energy at no incremental cost.

Gaffin et al. [35] constructed a general energy balance model applicable to both green and nongreen roof surfaces. In this study, the Penn State Center for Green Roof Research has developed and instrumented a green roof field experiment in Central Pennsylvania. The experiment consists of 6 separate buildings, 3 with green roofs and 3 with control dark roofs. The experimental results showed that the average temperature of green roofs was about $15^{\circ} \mathrm{F}$ lower in July.

An experiment increasing solar reflectance of the roof surface of a noncooled school building in Athens was carried out by Synnefa et al. [36]. A monitoring campaign was carried out before and after the application of a white elastomeric coating with a solar reflectance of 0.89 . The surface temperature of the building was measured, and the building was modeled into TRNSYS software and the model has been calibrated and validated using the experimental data. Simulation results showed a decrease in the air temperature of up to $2.8^{\circ} \mathrm{C}$ in the classrooms and surface temperature reduced up to about $25^{\circ} \mathrm{C}$ during summer period.

These findings show that green roofs or HR envelopes can reduce the surface temperatures of buildings; however, the thermal interactions between pavements and nearby objects need special attention due to their diffusive reflective properties. This interaction may not be seen as a problem in open areas, but it tends to be more serious in high density urban centers where walls are close to pavements or neighboring buildings. Thus, the lack of the previous research is less for the application of HR materials on the façade of buildings and the application of RR materials on the building envelopes. The RR material should mitigate the UHI effect if put into practice.

\section{Influence of HR Envelopes on Building Energy Consumption}

The global contribution from buildings towards energy consumption, both residential and commercial, has steadily increased to between $20 \%$ and $40 \%$ in developed countries and has exceeded the other major sectors: industrial and transportation [37]. Recently, efforts in reduction of primary energy consumption in the consumer business sector and university facilities have been examined [38-40]. During the past century, global population has become increasingly urbanized and turned cities into large energy consumers. Building energy consumption in cities is closely related to environmental temperature, where there are increased UHI intensity and heat wave events. Land use, land cover modification, and changes in global and regional climate patterns have led to increases in energy demand. Akbari et al.
[41] reported that, for the U.S. cities with populations larger than 100,000 people, peak electricity load will increase by $1.5-$ $2.0 \%$ for every $1^{\circ} \mathrm{F}$ increase in ambient temperature.

Many researches related to the impact of HR envelopes on the energy consumption have been carried out. These are summarized in Table 2.

Georgescu et al. [42] used the advanced research version of the weather research and forecasting model coupled to an urban canyon model (WRF3.2.1) to compare several plausible urban growth futures with climate change effects. They offer an extensive exploration of ranges of impacts and adaptation strategies. It showed that the winter heating penalty of HR coatings can reduce or even exceed the cooling energy savings in summer.

Akbari et al. [43] used the DOE-2 building energy simulation program to investigate the impact of roof reflectivity on cooling and heating energy use for buildings in the U.S. Savings are estimated for 11 US metropolitan statistical areas in a variety of climates. It showed that the largest savings for individual buildings were found in cities with the hottest and sunniest climates. Savings decreased as the climate gets cooler.

Levinson and Akbari [44] combined building energy simulations, local energy prices, local electricity emission factors, and local estimates of building density to characterize local, state average and national average cooling energy savings, heating energy penalties, energy cost savings, and emission reductions per-conditioned roof area (CRA) and per-land area (LA). The result was the potential annual rates of energy cost savings in 236 cities across the US after installing the cool roof. Additionally, Levinson and Akbari used the DOE-2.1-E model with a roof assembly heat transfer module to predict that a cool roof almost always reduced the annual cooling load more than it increased the annual heating load per-CRA, with the greatest saving in Hawaii and the least in Alaska.

Yaghoobian et al. [45] applied the Temperatures of Urban Facets in 3D (TUF3D) model and found that the low albedo of artificial turf (AT) relative to the other materials under investigation results in a reduction in shortwave radiation incident on nearby building external walls and an approximately equal increase in longwave radiation. Consequently, the overall building design cooling loads near AT decrease by $15 \%-20 \%$.

Zinzi and Agnoli [46] used EnergyPlus software to analyze the impact of cool and green roofs on the overall energy performance of buildings in different localities at Mediterranean latitudes. The numerical comparative analysis shows that the annual energy savings vary from $-13.7 \%$ to $41.7 \%$ by cool and green roofs.

Bianchi et al. [47] used Oak Ridge National Laboratory's Simplified Transient Analysis of Roofs (STAR) computer code to predict the transient heat gain and structure temperature. The numerical code was developed and used to generate the hourly temperature and heat flux through the thickness of insulation over an entire year. Results showed that the cool roofs can reduce the cooling loads by about $38 \%$ and increase the heating penalty by about $8.1 \%$ in Climate Zone 12 (Sacramento). 
TABLE 2: Summary of influence of HR envelopes on energy consumption.

\begin{tabular}{|c|c|c|c|}
\hline Reference & Methodology & Building type/region & Energy consumption \\
\hline$[42]$ & $\begin{array}{l}\text { Using WRF modeling } \\
\text { system. }\end{array}$ & $\begin{array}{l}\text { Urban regional climate } \\
\text { simulations in U.S. }\end{array}$ & $\begin{array}{l}\text { Winter heating penalty can reduce and roll back or } \\
\text { even exceed cooling energy savings in summer. }\end{array}$ \\
\hline$[43]$ & Using DOE-2 model. & $\begin{array}{l}\text { Residential and commercial } \\
\text { simulation buildings of } 11 \text { U.S. } \\
\text { metropolitan statistical areas. }\end{array}$ & $\begin{array}{l}\text { The total savings for all } 11 \text { metropolitan statistical areas } \\
\text { are annual electricity savings, } 2.6 \mathrm{TWh} \text {; peak electricity } \\
\text { demand savings, } 1.7 \mathrm{GW} \text {. }\end{array}$ \\
\hline$[44]$ & Using DOE2.1-E model. & $\begin{array}{l}\text { Four commercial building } \\
\text { prototypes simulations in } \\
236 \text { US cities. }\end{array}$ & $\begin{array}{l}\text { 3.3-7.69 } \mathrm{kWh} / \mathrm{m}^{2} \text { energy saving for annual cooling, } \\
0.003-0.065 \text { therm } / \mathrm{m}^{2} \text { heating penalty for } 236 \text { cities in } \\
\text { U.S. }\end{array}$ \\
\hline$[45]$ & $\begin{array}{l}\text { Applying the Temperatures } \\
\text { of Urban Facets in 3D } \\
\text { (TUF3D) model. }\end{array}$ & $\begin{array}{l}\text { TUF3D model simulation } \\
\text { domain with buildings and } \\
\text { ground with } 25 \text { buildings in } \\
\text { Southern California. }\end{array}$ & $\begin{array}{l}\text { Overall building design cooling loads near artificial turf } \\
\text { (AT) decrease by } 15 \%-20 \% \text {. The irrigation water } \\
\text { conservation with AT causes embodied energy savings } \\
\text { of } 10 \mathrm{Wh} / \mathrm{m}^{2} \cdot \text { day. Radiative energy from ground to wall } \\
\text { increases with increasing the albedo of the nearby } \\
\text { ground materials. }\end{array}$ \\
\hline$[46]$ & Using EnergyPlus software. & $\begin{array}{l}\text { Residential simulation } \\
\text { buildings in different } \\
\text { localities at Mediterranean } \\
\text { latitudes. }\end{array}$ & Annual energy savings range from $-13.7 \%$ to $41.7 \%$. \\
\hline$[47]$ & $\begin{array}{l}\text { Applying Simplified } \\
\text { Transient Analysis of Roofs } \\
\text { (STAR) computer code. }\end{array}$ & $\begin{array}{l}\text { Simulations in } 16 \text { California } \\
\text { climate zones. }\end{array}$ & $\begin{array}{l}\text { Cooling load decreased by about } 38 \% \text { per year; heating } \\
\text { penalty increased by about } 8.1 \% \text { per year for Climate } \\
\text { Zone } 12 .\end{array}$ \\
\hline
\end{tabular}

These studies above show that the HR envelope, including cool and green roofs (roof covered with plants), can reduce the energy consumption of buildings for cooling loads in summer. However, it can increase the heating penalty of buildings in winter. Thus, in order to solve this problem that may increase the heating loads in winter, the measure of applying the combination of thermal insulation and cool envelope of building external walls was proposed to minimize the energy consumption of buildings. In addition, as water stress due to climate change and population growth worsens [49], it becomes more difficult and costly maintains the water supply to manage the green roofs. Therefore, instead of a green roof, the application of more effective HR or RR roof is strongly encouraged to save energy of buildings and UHI mitigation.

\section{Potential of Application of RR Materials for Building Envelopes}

RR materials reflect much of the incoming sunlight back to the incident direction, as shown in Figures 1(a) and (b). If applied to building external walls, the RR envelope would prevent much of the reflection of light to roads and surrounding building caused by HR envelopes, as shown in Figures 2(a) and 2(b). Thus, RR envelopes should help to mitigate the UHI, while still having the same potential for energy savings as an HR envelope.

4.1. Methods to Determine Retroreflectance of RR Materials. Before applying RR materials for building external walls, the RR performance has to be analyzed in detail. For methods to determine the retroreflectance of building envelopes, many researchers have defined it through means of experiments and models. Also the impacts of RR envelope on energy consumption of buildings and UHI mitigation were examined globally. The research on RR materials carried out by different researchers was summarized in Table 3 and stated as follows.

Akbari and Touchaei proposed calculating the hourly reflectance of directional reflective materials (DRMs) by using a developed model as a function of zenith and azimuth angles [16]. Two main options are proposed for labeling: one is using one reflectance for the whole year, and the other is using seasonal reflectance, including summer reflectance, winter reflectance, and mean reflectance of summer and winter. A simple method based on seasonal reflectance was proposed, assigning the average reflectance of DRMs as the winter reflectance and the reflectance of the DRM according to a $20^{\circ}$ zenith towards the reflective side as the summer reflectance. Errors of estimated energy saving were calculated separated by summer and winter.

Rossi et al. [18] assessed the angular reflectance of 5 types of RR films for several inclination angles of solar radiation from $10^{\circ}$ to $80^{\circ}$ in steps of $10^{\circ}$ interval, by using an ad hoc experimental setup, and evaluated RR materials' potential for UHI mitigation by a $2 \mathrm{D}$ analytic model.

Nishioka et al. [22] evaluated the directional reflective performance of RR materials configured by a three-mirror and a four-mirror type of corner, using geometrical optical principle. The RR effective area of three-mirror or fourmirror type of corner reflectors was defined, and the relationship between the incident angle and the RR effective area was also examined. However, there was no specific discussion on the energy saving of buildings and UHI mitigation.

Yuan et al. [19, 20] proposed a method to determine the retroreflectance of $\mathrm{RR}$ materials by subtracting the 


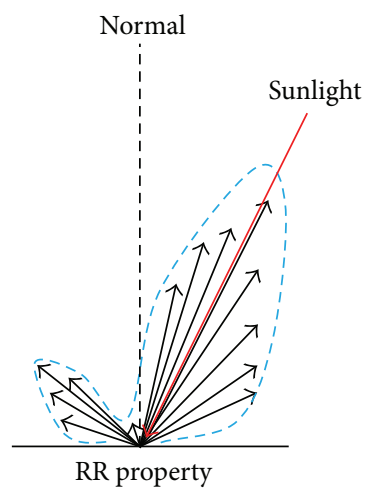

(a)

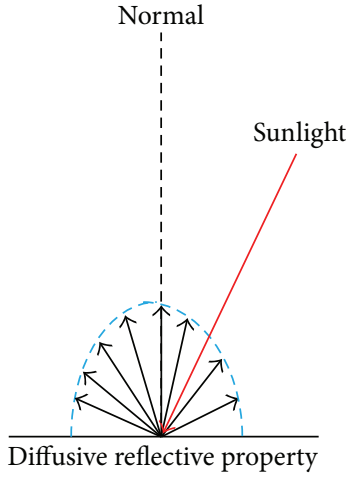

(b)

FIGURE 1: Reflection directivity characteristics of RR material and diffusive reflective material ((a) RR material; (b) diffusive reflective material).
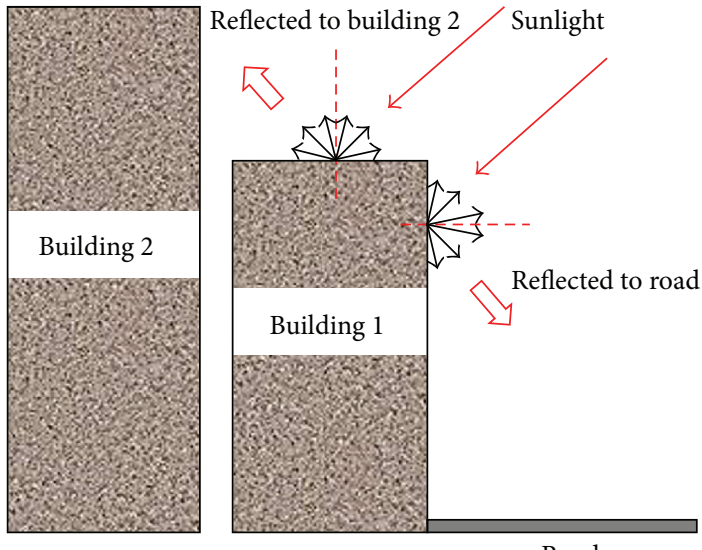

(a)
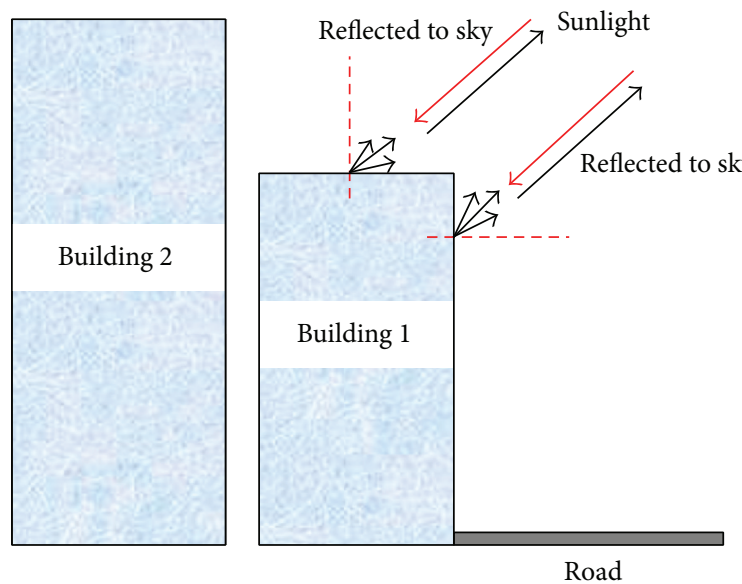

(b)

FIGURE 2: Example of solar radiation reflected by two types of building coatings ((a) diffusive HR coatings; (b) RR coatings).

solar reflectance measured with spectrophotometer from the solar reflectance evaluated by the thermal balance from temperatures measured in the outdoor environment. The error of retroreflectance takes into account the wind speed measurement of $2 \%$, which yields an error of up to 0.004 in the solar reflectance evaluated by the thermal balance in Yuan's method [19]. The experimental reflective plate was taken into account as the main error and a revision method for retroreflectance was also proposed by Yuan et al.s research [48].

The research by Han et al. [23] has evaluated the impact of RR envelope on surface temperature and primary energy for heating and cooling, using simulations and EnergyPlus software which is an energy analysis and thermal load simulation engine distribution by the U.S. Department of Energy. The average temperature reductions of the control building surface during daytime at typical seasonal days in Miami and Minneapolis cities were examined between RR testing and regular diffusive façades by simulation numerical analysis. The analyzed result showed that the average temperature of simulation building envelopes when RR pattern diffusive wall was used for testing surface is about $0.46^{\circ} \mathrm{C}$ lower than it of condition when a regular diffusive wall was used for testing surface during daytime at typical summer days in Miami and about $0.42^{\circ} \mathrm{C}$ reduction in Minneapolis.

4.2. Potentiality of RR Materials for UHI Mitigation by Simulations. RR envelopes could contribute to reduce the energy consumption of buildings and the UHI effect, because a part of the solar radiation is sent back towards the incoming direction $[18,20,26]$. In particular, RR envelopes can strongly reduce the mutual radiative effect among buildings located in close proximity [23].

Yuan et al. [20] have developed a type of RR materials and investigated its durability and RR performance by evaluating changes in retroreflectance for a long time period exposed to the outdoor environment. The influence of different reflective characteristics on the albedo of urban canyons was simulated and analyzed. The results showed that the albedo of simulated urban canyons with RR envelopes is the largest, about $6.1 \%$ larger than those with diffusive reflective envelopes and about 9.4\% larger than those with mirror reflective envelope. 
TABLE 3: Summary of several current studies of RR materials applied for building envelopes.

\begin{tabular}{|c|c|c|}
\hline Reference & Method to derive retroreflectance & Energy saving, urban albedo, UHI mitigation, and so forth \\
\hline$[16]$ & $\begin{array}{l}\text { Model to calculate the hourly } \\
\text { reflectance of directional reflective } \\
\text { materials (DRMs) as a function of } \\
\text { zenith and azimuth angles. }\end{array}$ & $\begin{array}{l}\text { In summer, the selected metric estimates the mean energy } \\
\text { saving for building energy models accurately and the peak heat } \\
\text { absorption of surface by } 8 \%\left(<40 \mathrm{~W} / \mathrm{m}^{2}\right) \text { error. In winter, the } \\
\text { potential energy savings of buildings are overestimated by an } \\
\text { error of less than } 20 \% \text {, and mean hourly and peak heat } \\
\text { absorptions are estimated by the error of } 22 \mathrm{~kJ} / \mathrm{m}^{2} \text { and } 9 \mathrm{~W} / \mathrm{m}^{2} \text {, } \\
\text { respectively. }\end{array}$ \\
\hline [18] & $\begin{array}{l}\text { An ad hoc experimental setup was } \\
\text { designed and used for assessing the } \\
\text { angular reflectance of RR films. }\end{array}$ & $\begin{array}{l}\text { The potential of RR materials for mitigating UHI was estimated } \\
\text { in terms of cooling potential, defined as a decrease of circulating } \\
\text { energy contributing to the canyon overheating, through a } 2 \mathrm{D} \\
\text { algorithm. The decrease of the energy kept inside the canyon } \\
\text { due to the use of } \mathrm{RR} \text { materials has been evaluated for three } \\
\text { values of latitude }\left(30^{\circ}, 40^{\circ} \text {, and } 50^{\circ}\right) \text { with a south-exposed } \\
\text { façade. In addition, the effect of RR materials on the energy } \\
\text { circulating inside the canyon has been evaluated also for } \\
\text { different façade exposures (south, east, and west). }\end{array}$ \\
\hline
\end{tabular}

Using two sorts of a 3-mirror type and a 4-mirror type of corner reflectors and geometrical optical analysis method to evaluate the reflection performance to the direct-beam solar radiation and $\mathrm{RR}$ properties of RR materials.
$[19,20,48] \quad$ spectrophotometer measurement and thermal measurement in the outdoor environment.
The RR effective area of 3-mirror or 4-mirror type of corner reflectors was defined, and the relationship between the incident angle and the RR effective area was also examined. However, there was no specific discussion on the energy saving of buildings and UHI mitigation.

The urban albedo was carried out by using a simple 2D shape and Monte Carlo theory, with different reflective characteristics of building envelope materials. The results showed that the RR envelope of buildings is more effective to increase the albedo of urban canyons than the other diffusive or mirror reflective envelopes. Also the impact of RR envelope on thermal loads of buildings was examined by simulation building and New HASP/ACLD- $\beta$. The results indicated that RR building envelopes can decrease the annual cooling loads as well as the annual total thermal loads and increase the annual heating loads.

The average temperature reductions of the control building surface during daytime at typical seasonal days in Miami and Minneapolis cities were examined between RR testing and regular diffusive façade by simulation numerical analysis. A cross-regional energy analysis of eight cities in U.S. was also examined by simulation numerical analysis.
Rossi et al. [18, 26] have evaluated the mitigation effects of RR materials in UHI scenarios by experimental campaign and a novel analytical model. Five RR samples and one diffusive sample were chosen and their reflection directivity characteristics were tested. As discussed by Rossi et al.'s studies, all RR samples show an RR behavior only for low incidence angles of sunlight. Then for higher angles of incidence, the radiation is mainly specularly reflected. The potentiality of RR materials for mitigating UHI was estimated in terms of cooling potential. Comparing the cooling potential of a $\mathrm{RR}$ envelope to a diffusive reflective envelope, it showed that the cooling potential of a high-intensity prismatic RR sample with south-facing is about $1.5 \%$ better for latitude of $30^{\circ}$, evaluated by the analytical model.

In order to describe the potential impact of the RR material on energy behavior, Han et al. [23] have used
EnergyPlus software to analyze the thermal-energy impact in neighboring buildings in an urban context where buildings are in close proximity. Due to different reflective façades with RR and regular diffusive characteristics, a cross-regional energy analysis of eight cities was examined. It revealed reductions of cooling energy consumption under the RR context for both total energy consumption and cooling energy consumption of HVAC, by up to $8.2 \%$ and $9.8 \%$ in different metropolitan areas. The result showed that a bioinspired RR façade can reduce the energy required for cooling loads of buildings and lessen the reflected heat of solar radiation in spatially proximal buildings leading to reducing the UHI effects.

4.3. Potentiality of $R R$ Materials by Economic Analysis. In order to put RR materials into practice as a building envelope, 
RR materials not only have better reflective directional properties compared to HR materials, but also meet the low cost from the viewpoint of economics. However, the benefit of RR over HR is to the neighboring buildings, not to the occupants of the building which installs RR envelopes. As costs for $\mathrm{RR}$ are likely higher than $\mathrm{HR}$, there is little incentive to the individual building owner. Yet, if all buildings install RR, all occupants and the entire city would benefit. Thus, the calculation of economic benefit from RR envelopes should be on the urban planning scale. Based on the analysis method to definite the optimum insulation thickness from considering the cost of building external walls [50-53], we proposed a method to determine the economic benefit of RR materials in this paper, as described in detailed steps:

(i) First step: to determine the optimum overall reflectivity of RR materials for different geographical locations through calculating the annual cooling load of buildings.

(ii) Second step: to investigate the price of RR materials with the optimum overall reflectivity in local commercially available material market.

(iii) Third step: to consider the combination of RR materials and insulation materials for reducing the total thermal loads of buildings.

(iv) Fourth step: to analyze the total cost per unit area of external wall $\left(C_{t}\right)$ over the building envelope lifetime $(n)$ that includes the cost of insulation material $\left(C_{\text {ins }}\right)$, RR material $\left(C_{\text {ret }}\right)$, and energy consumption $\left(C_{\text {ene }}\right)$ in the local market.

(v) Fifth step: to find the lowest total cost of building external walls $\left(C_{t}\right)$ with the optimum RR material.

The total cost per unit area of external wall $\left(C_{t}\right)$ is given by the following equation:

$$
C_{t}=C_{\mathrm{ins}}+C_{\mathrm{ret}}+C_{\mathrm{ene}}=L_{\mathrm{ins}} \cdot c_{i}+C_{\mathrm{ret}}+c_{e} \cdot \mathrm{PWF}
$$

where $C_{\text {ins }}$ is the cost of the insulation material, $C_{\text {ret }}$ is the cost of RR material of building envelope, $C_{\text {ene }}$ is the cost of energy consumption over the building envelope lifetime, $L_{\text {ins }}$ is the insulation thickness, $c_{i}$ is the cost of insulation material per unit volume, $c_{e}$ is the current annual total lifetime cost of energy, and PWF is the present worth factor [54].

The current annual total cost of energy $\left(c_{e}\right)$ is calculated separately for the heat gain (cooling load) and the heat loss (heating load), and it is shown in

$$
\begin{aligned}
c_{e} & =W_{e} \cdot E, \\
W_{e} & =W_{e, c}+W_{e, h}, \\
W_{e, c} & =\frac{Q_{g}}{P_{c}}, \\
W_{e, h} & =\frac{Q_{l}}{P_{h}},
\end{aligned}
$$

where $W_{e}$ is the total energy consumption per unit area, $E$ is electricity rate in US dollars per $\mathrm{kWh}, W_{e, c}$ is the annual energy consumption for cooling per unit area, $W_{e, h}$ is the annual energy consumption for heating per unit area, $Q_{g}$ is the total heat gain per square meter per year (the cooling load), $Q_{l}$ is the total heat loss per square meter per year (the heating load), $P_{c}$ is the average coefficient of performance (COP) of the air-conditioning system for cooling, and $P_{h}$ is the average COP of the air-conditioning system for heating.

Total cost is evaluated together with the present worth factor PWF for the building envelope lifetime of $n$ years. The PWF depends on the inflation rate in energy cost $r_{i}$, and the interest rate $r_{d}$. Equations for deriving PWF are shown in the following equations.

$$
\begin{aligned}
& \text { In case } r_{i} \neq r_{d} \text {, then } \\
& \qquad \mathrm{PWF}=\left[\frac{\left(1+r_{i}\right)}{\left(r_{d}-r_{i}\right)}\right] \cdot\left\{1-\left[\frac{\left(1+r_{i}\right)}{\left(1+r_{d}\right)}\right]^{n}\right\} . \\
& \text { In case } r_{i}=r_{d} \text {, then } \\
& \qquad \operatorname{PWF}=\frac{n}{\left(1+r_{d}\right)} .
\end{aligned}
$$

These above parameters used in calculating $C_{t}$ are based on market cost and conditions of RR application locations.

The total of $C_{t}$ for buildings in a chosen area, from the scale of part of a single urban canyon affected by one building installing a RR envelope to an entire city district installing RR envelopes in all buildings would show the net benefit. This could then be a guide to government or energy companies in creating financial incentive plans to encourage installation of RR envelopes.

As the conditions vary widely (material and energy cost, building size, urban geography, climate conditions, etc.), the results could show whether RR envelopes can be economical or of what price level they become so.

\section{Conclusion}

While the HR material applied as building envelope has become popular as an important UHI mitigation strategy, its relevant impacts, especially on the surface temperature of surrounding buildings and energy consumption of buildings, are not clearly classified or summarized and vary widely depending on conditions. Therefore, we summarized recent research advances of $\mathrm{HR}$ envelopes on reducing the UHI effect from many previous studies in this review paper. Although HR envelopes can mitigate the UHI effect and reduce the energy consumption of buildings, there are still many defects for HR envelopes in terms of UHI mitigation and energy saving of buildings, which are known through previous studies and shown as follows.

(i) HR envelope can reflect some solar radiation to the sky and also onto neighboring buildings and roads. If there are high buildings nearby, even more of the reflection by HR envelopes will be absorbed rather than being reflected to the sky. Thus, HR envelopes have a limited effect against the solar contribution to 
the UHI. HR materials are commonly applied to the roof of buildings. However, its application to vertical walls of buildings is not widely implemented at present. RR materials would avoid this issue yielding greater UHI mitigation by application to external walls.

(ii) As urban water supplies are expected to be increasingly stressed worldwide, the maintenance of green roofs will become more difficult. Thus, the development of more effective HR materials of roofs, rather than use of green roofs, is strongly encouraged to mitigate the UHI effect and reduce energy consumption of buildings.

(iii) HR envelopes can reduce the energy consumption for cooling load in summer but may increase the energy consumption for heating load in winter, especially in locations with cold winter. Therefore, the combination of HR envelopes for reducing cooling load of buildings in summer and thermal insulation of external walls for decreasing heating load of buildings in winters should also be considered and proposed as an effective countermeasure to reduce the total thermal loads of buildings.

(iv) Influence of RR envelope and diffusive HR envelope on UHI mitigation regarding the cooling potential or albedo of urban canyons has been compared in simulations. The simulations showed that the RR material is more effective than the diffusive HR material in terms of reducing cooling energy consumption of HVAC and increasing albedo of urban canyons.

In summary, based on several opinions mentioned above, more efficient RR materials which can reflect the solar radiation back towards the source are encouraged to be applied as building envelopes instead of HR materials, especially, for the application to the façade of buildings. In addition, taking into account the adverse effects of reflective materials on the heating load in winter, the optimum combination of $\mathrm{RR}$ envelope and thermal insulation of external walls must be better considered to minimize the energy consumption of buildings from the economic analysis due to regions with different climatic characteristics in the future research. Because RR materials prices can widely vary worldwide, are generally not available in commercial form for application to building external walls, and have not been long-term tested for durability in such use, it is difficult to carry out a generally applicable cost analysis. In specific markets, it may be possible as outlined here. Looking beyond the potential for UHI mitigation and energy saving of urban constructions, city planners and policy makers should not only be aware of but also set up standards in quantifying potential environmental impacts of RR materials in addition to or in place of $\mathrm{HR}$ materials.

\section{Highlights}

(i) We summarized impact of HR envelopes on the surface temperature from several previous studies. (ii) We summarized impact of HR envelopes on energy consumption of buildings from previous studies.

(iii) We reviewed main methods to determine retroreflectance of RR materials from several current studies.

(iv) We reviewed simulations showing the potential of RR materials for UHI mitigation and energy savings.

(v) We stated viewpoint of applying RR materials to façade of buildings considering environmental factors.

\section{Conflict of Interests}

The authors declare that there is no conflict of interests regarding the publication of this paper.

\section{References}

[1] C. Aniello, K. Morgan, A. Busbey, and L. Newland, "Mapping micro-urban heat islands using Landsat TM and a GIS," Environmental Geology, vol. 21, no. 8, pp. 965-969, 1995.

[2] F. Salamanca, M. Georgescu, A. Mahalov, M. Moustaoui, M. Wang, and B. M. Svoma, "Assessing summertime urban air conditioning consumption in a semiarid environment," Environmental Research Letters, vol. 8, no. 3, Article ID 034022, 9 pages, 2013.

[3] S. Hassid, M. Santamouris, N. Papanikolaou et al., "The effect of the Athens heat island on air conditioning load," Energy and Buildings, vol. 32, no. 2, pp. 131-141, 2000.

[4] C. Sarrat, A. Lemonsu, V. Masson, and D. Guedalia, "Impact of urban heat island on regional atmospheric pollution," Atmospheric Environment, vol. 40, no. 10, pp. 1743-1758, 2006.

[5] E. S. Cozza, M. Alloisio, A. Comite, G. Di Tanna, and S. Vicini, "NIR-reflecting properties of new paints for energy-efficient buildings," Solar Energy, vol. 116, pp. 108-116, 2015.

[6] M. Dabaieh, O. Wanas, M. A. Hegazy, and E. Johansson, "Reducing cooling demands in a hot dry climate: a simulation study for non-insulated passive cool roof thermal performance in residential buildings," Energy and Buildings, vol. 89, pp. 142152, 2015.

[7] A. L. Pisello, F. Cotana, and L. Brinchi, "On a cool coating for roof clay tiles: development of the prototype and thermalenergy assessment," Energy Procedia, vol. 45, pp. 453-462, 2014.

[8] E. Bozonnet, M. Musy, I. Calmet, and F. Rodriguez, "Modeling methods to assess urban fluxes and heat island mitigation measures from street to city scale," International Journal of LowCarbon Technologies, vol. 10, no. 1, pp. 62-77, 2015.

[9] A. Synnefa, M. Santamouris, and I. Livada, "A study of the thermal performance of reflective coatings for the urban environment," Solar Energy, vol. 80, no. 8, pp. 968-981, 2006.

[10] M. Santamouris, A. Synnefa, and T. Karlessi, "Using advanced cool materials in the urban built environment to mitigate heat islands and improve thermal comfort conditions," Solar Energy, vol. 85, no. 12, pp. 3085-3102, 2011.

[11] A. Synnefa and M. Santamouris, "Advances on technical, policy and market aspects of cool roof technology in Europe: the Cool Roofs project," Energy and Buildings, vol. 55, pp. 35-41, 2012.

[12] J. Zou, P. Zhang, C. Liu, and Y. Peng, "Highly dispersed (Cr, Sb)co-doped rutile pigments of cool color with high near-infrared reflectance," Dyes and Pigments, vol. 109, pp. 113-119, 2014. 
[13] T. Inoue, "Solar radiation shielding technique," Building Technology, vol. 684, pp. 142-145, 2007 (Japanese).

[14] H. Sakai, K. Emura, N. Igawa, and H. Iyota, "Reduction of reflected heat of the sun by retroreflective materials," in Proceedings of the 2 nd International Conference on Countermeasures to Urban Heat Islands (SICCUHI '09), pp. 1-6, Berkeley, Calif, USA, September 2009.

[15] J. Yuan, K. Emura, and H. Sakai, "Evaluation of the solar reflectance of highly reflective roofing sheets installed on building roofs," Journal of Building Physics, vol. 37, no. 2, pp. 170-184, 2013.

[16] H. Akbari and A. G. Touchaei, "Modeling and labeling heterogeneous directional reflective roofing materials," Solar Energy Materials and Solar Cells, vol. 124, pp. 192-210, 2014.

[17] H. Akbari and H. D. Matthews, "Global cooling updates: reflective roofs and pavements," Energy and Buildings, vol. 55, pp. 2-6, 2012.

[18] F. Rossi, B. Castellani, A. Presciutti et al., "Retroreflective façades for urban heat island mitigation: experimental investigation and energy evaluations," Applied Energy, vol. 145, pp. 8-20, 2015.

[19] J. Yuan, K. Emura, and C. Farnham, "A method to measure retro-reflectance and durability of retro-reflective materials for building outer walls," Journal of Building Physics, vol. 38, no. 6, pp. 500-516, 2015.

[20] J. Yuan, C. Farnham, and K. Emura, "Development of a retroreflective material as building coating and evaluation on albedo of urban canyons and building heat loads," Energy and Buildings, vol. 103, pp. 107-117, 2015.

[21] J. Yuan, K. Emura, and C. Farnham, "Geometrical-optics analysis of reflective glass beads applied to building coatings," Solar Energy, vol. 122, pp. 997-1010, 2015.

[22] M. Nishioka, S. Inoue, and K. Sakai, "Retroreflective properties calculating method based on geometrical-optics analysis," Journal of Environmental Engineering, vol. 73, no. 633, pp. 1249-1254, 2008 (Japanese).

[23] Y. Han, J. E. Taylor, and A. L. Pisello, “Toward mitigating urban heat island effects: Investigating the thermal-energy impact of bio-inspired retro-reflective building envelopes in dense urban settings," Energy and Buildings, vol. 102, pp. 380-389, 2015.

[24] V. D. Maria, M. Rahman, P. Collins, G. Dondi, and C. Sangiorgi, "Urban Heat Island Effect: thermal response from different types of exposed paved surfaces," International Journal of Pavement Research and Technology, vol. 6, no. 4, pp. 414-422, 2013.

[25] A. L. Pisello, F. Cotana, A. Nicolini, and L. Brinchi, "Development of clay tile coatings for steep-sloped cool roofs," Energies, vol. 6, no. 8, pp. 3637-3653, 2013.

[26] F. Rossi, A. L. Pisello, A. Nicolini, M. Filipponi, and M. Palombo, "Analysis of retro-reflective surfaces for urban heat island mitigation: a new analytical model," Applied Energy, vol. 114, pp. 621-631, 2014.

[27] H. H. Saber, "Investigation of thermal performance of reflective insulations for different applications," Building and Environment, vol. 52, pp. 32-44, 2012.

[28] A. L. Pisello, G. Pignatta, V. L. Castaldo, and F. Cotana, "Experimental analysis of natural gravel covering as cool roofing and cool pavement," Sustainability, vol. 6, no. 8, pp. 4706-4722, 2014.

[29] M. Santamouris, N. Gaitani, A. Spanou et al., "Using cool paving materials to improve microclimate of urban areasdesign realization and results of the flisvos project," Building and Environment, vol. 53, pp. 128-136, 2012.
[30] D. Millstein and S. Menon, "Regional climate consequences of large-scale cool roof and photovoltaic array deployment," Environmental Research Letters, vol. 6, no. 3, Article ID 034001, 9 pages, 2011.

[31] H. Takebayashi and M. Moriyama, "Surface heat budget on green roof and high reflection roof for mitigation of urban heat island," Building and Environment, vol. 42, no. 8, pp. 2971-2979, 2007.

[32] C. Romeo and M. Zinzi, "Impact of a cool roof application on the energy and comfort performance in an existing nonresidential building. A Sicilian case study," Energy and Buildings, vol. 67, pp. 647-657, 2013.

[33] M. T. Simmons, B. Gardiner, S. Windhager, and J. Tinsley, "Green roofs are not created equal: the hydrologic and thermal performance of six different extensive green roofs and reflective and non-reflective roofs in a sub-tropical climate," Urban Ecosystems, vol. 11, no. 4, pp. 339-348, 2008.

[34] H. Akbari, "Measured energy savings from the application of reflective roofs in two small non-residential buildings," Energy, vol. 28, no. 9, pp. 953-967, 2003.

[35] S. Gaffin, C. Rosenzweig, L. Parshall et al., "Energy balance modeling applied to a comparison of white and green roof cooling efficiency," Green Roofs in the New York Metropolitan Region Research Report, 2010.

[36] A. Synnefa, M. Saliari, and M. Santamouris, "Experimental and numerical assessment of the impact of increased roof reflectance on a school building in Athens," Energy and Buildings, vol. 55, pp. 7-15, 2012.

[37] L. Pérez-Lombard, J. Ortiz, and C. Pout, "A review on buildings energy consumption information," Energy and Buildings, vol. 40, no. 3, pp. 394-398, 2008.

[38] T. Ohashi, M. Miyazaki, K. Taku, and Y. Shimoda, "Estimation of energy end-use breakdown in science research facilities," Journal of Environmental Engineering, vol. 79, no. 699, pp. 443450, 2014 (Japanese).

[39] J. Zhang, L. Xu, Y. Nakajima, and H. Takakuchi, "Energy consumption survey in a high-rise university: comparison of energy consumption before and after the Great East Japan Earthquake," Journal of Environmental Engineering, vol. 79, no. 699, pp. 451-458, 2014 (Japanese).

[40] R. Miki, D. Nishina, S. Murakawa, and S. Kindaichi, "Study on the energy consumption of aged welfare facilities with habitation in the Chugoku and Shikoku regions," Journal of Environmental Engineering, vol. 79, no. 699, pp. 459-467, 2014 (Japanese).

[41] H. Akbari, D. Susan, D. Sofia, J. H. Yu, and W. Steven, Cooling Our Communities: A Guidebook on Tree Planting and LightColored Surfacing, Climate Change Division, United States Environmental Protection Agency, 1992.

[42] M. Georgescu, P. E. Morefield, B. G. Bierwagen, and C. P. Weaver, "Urban adaptation can roll back warming of emerging megapolitan regions," Proceedings of the National Academy of Sciences of the United States of America, vol. 111, no. 8, pp. 29092914, 2014.

[43] H. Akbari, S. Konopacki, and M. Pomerantz, "Cooling energy savings potential of reflective roofs for residential and commercial buildings in the United States," Energy, vol. 24, no. 5, pp. 391-407, 1999.

[44] R. Levinson and H. Akbari, "Potential benefits of cool roofs on commercial buildings: conserving energy, saving money, and reducing emission of greenhouse gases and air pollutants," Energy Efficiency, vol. 3, no. 1, pp. 53-109, 2010. 
[45] N. Yaghoobian, J. Kleissl, and E. S. Krayenhoff, "Modeling the thermal effects of artificial turf on the urban environment," Journal of Applied Meteorology and Climatology, vol. 49, no. 3, pp. 332-345, 2010.

[46] M. Zinzi and S. Agnoli, "Cool and green roofs. An energy and comfort comparison between passive cooling and mitigation urban heat island techniques for residential buildings in the Mediterranean region," Energy and Buildings, vol. 55, pp. 66-76, 2012.

[47] M. V. Bianchi, A. O. Desjarlais, W. A. Miller, and P. T. W. Petrie, "Cool roofs and thermal insulation: energy savings and peak demand reduction," in Proceedings of the ASHRAE Conference in Thermal Performance of the Exterior Envelopes of Buildings, vol. 10, pp. 1-6, Clearwater, Fla, USA, December 2007.

[48] J. Yuan, C. Farnham, and K. Emura, "A study on the accuracy of determining the retro-reflectance of retro-reflective material by heat balance," Solar Energy, vol. 122, pp. 419-428, 2015.

[49] H. Akbari and S. Konopacki, "Energy effects of heat-island reduction strategies in Toronto, Canada," Energy, vol. 29, no. 2, pp. 191-210, 2004.

[50] N. Sisman, E. Kahya, N. Aras, and H. Aras, "Determination of optimum insulation thicknesses of the external walls and roof (ceiling) for Turkey's different degree-day regions," Energy Policy, vol. 35, no. 10, pp. 5151-5155, 2007.

[51] J. Yu, C. Yang, L. Tian, and D. Liao, "A study on optimum insulation thicknesses of external walls in hot summer and cold winter zone of China," Applied Energy, vol. 86, no. 11, pp. 2520 2529, 2009.

[52] Ö. A. Dombayci, M. Gölcü, and Y. Pancar, "Optimization of insulation thickness for external walls using different energysources," Applied Energy, vol. 83, no. 9, pp. 921-928, 2006.

[53] K. Çomakli and B. Yüksel, "Optimum insulation thickness of external walls for energy saving," Applied Thermal Engineering, vol. 23, no. 4, pp. 473-479, 2003.

[54] S. A. Al-Sanea, M. F. Zedan, S. A. Al-Ajlan, and A. S. Abdul Hadi, "Heat transfer characteristics and optimum insulation thickness for cavity walls," Journal of Thermal Envelope and Building Science, vol. 26, no. 3, pp. 285-307, 2003. 


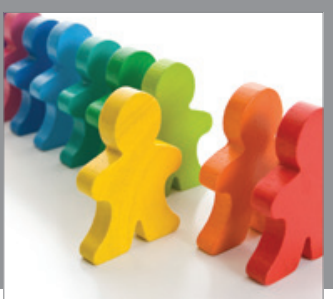

Autism

Research and Treatment
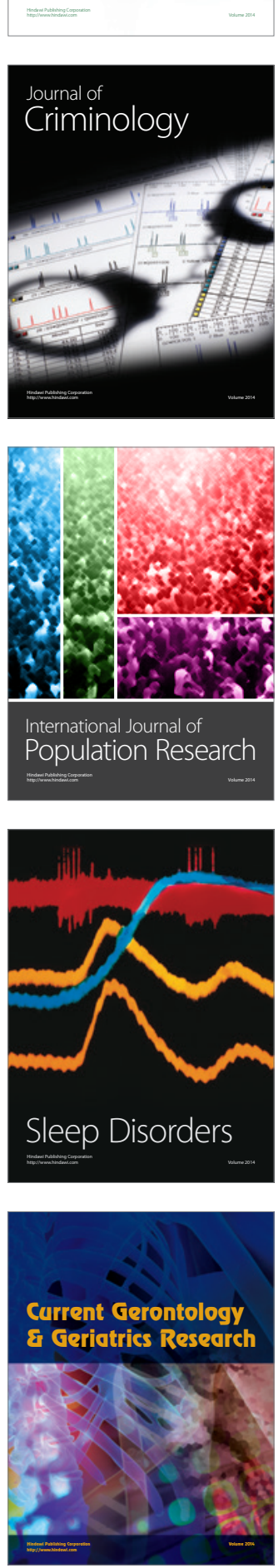

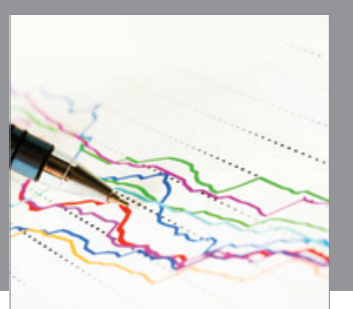

Economics

Research International
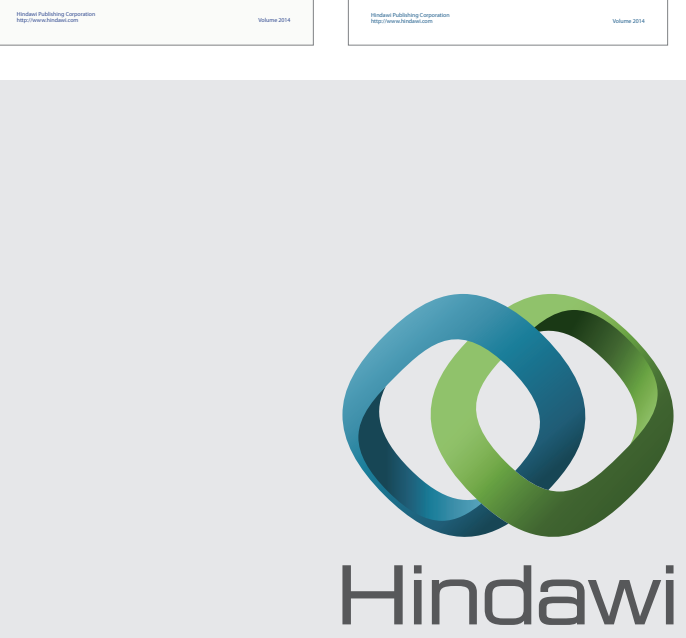

Submit your manuscripts at

http://www.hindawi.com
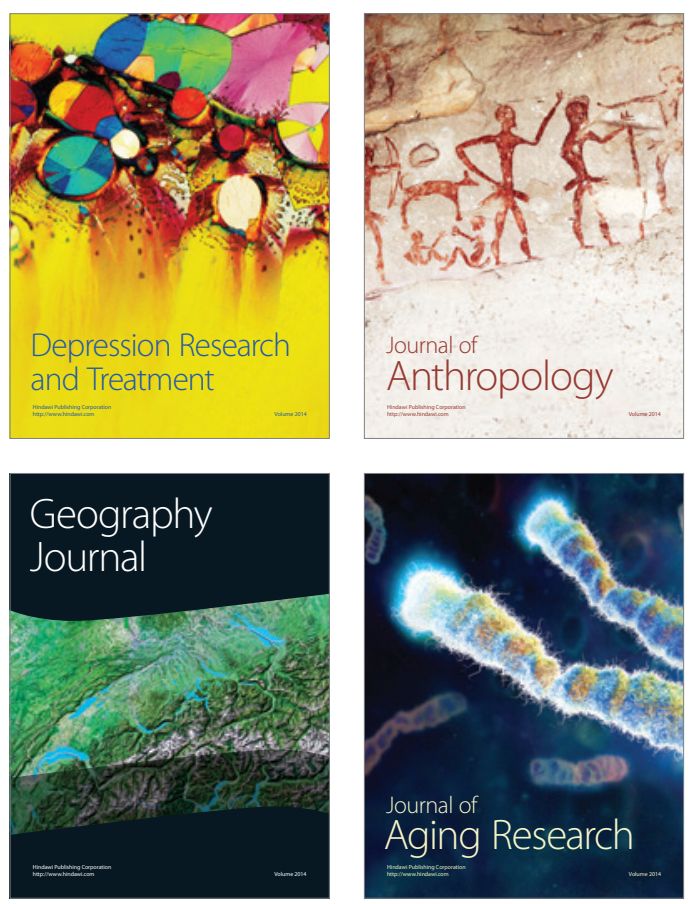
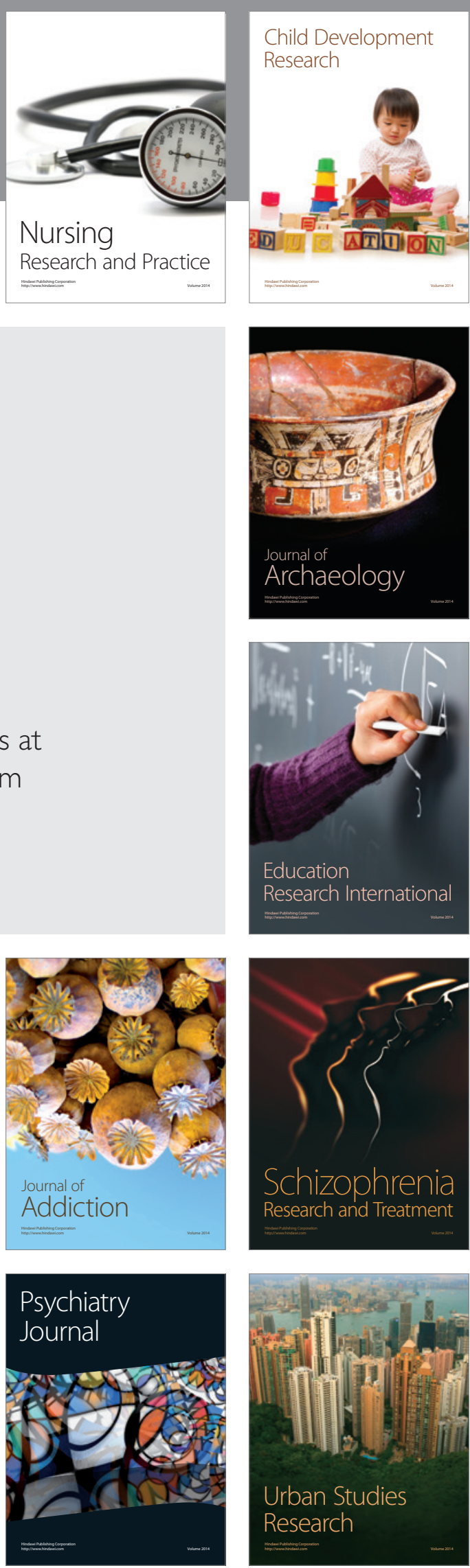